\section{Bioética e Terreiro: reflexões sobre práticas de sáude e cuidado no Tambor de Cura do Maranhão}

Saraiva, Luís Augusto F

Doutorando em Bioética pela Universidade de Brasília UnB.E-mail: luisferrarafilos@gmail.com

PALAVRAS-CHAVE: Bioética da Intervenção. Saúde da Populção Negra. Vulnerabilidade. Racismo. Religões Afroameríndias.

RESUMO: $O$ presente trabalho tem como objetivo investigar a prática do Tambor de Cura, ritual religioso afroamaríndio praticado no Maranhão a fim de compreender em que medida esses conhecimentos tradicionais auxiliam na promoção da saúde da população local do povoado de Santo Antônio dos Pretos, Maranhão. Tendo em vista que Maranhão, pela sua grande presença negra, pode ser tomado como uma presença da África no Brasil, configuração resultante do processo de diáspora em que inúmeras etnias africanas que viviam de modo complexo e que possuíam relações particulares com o sagrado e com a natureza, além de organizações políticas e estruturas sociais diversificadas foram tragadas pelo violento sistema escravista que levou homens e mulheres que viviam livres no continente africano a viverem do outro lado do Atlântico subjugadas e subjugados pelo trabalho forçado. Levando-se em consideração o legado africano que pode ser identificado nas distintas regiões do Brasil, o Maranhão é o Estado que mantêm de maneira evidente as manifestações culturais afrobrasileiras e de religiões de matriz africana se compondo enquanto uma experiência da África no Brasil. Em municípios no interior do Estado como Codó e o seu povoado de Santo Antônio dos Pretos, são encontradas práticas religiosas com ênfase terapêutico na cura de determinas doenças por meio de ervas, orações, pequenas "cirurgias" e aconselhamentos espirituais. Todo esse conjunto de saberes é chamado de Tambor de Cura ou Pajelança, que segundo a Antropóloga Mundicarmo Ferretti; "A Cura é muito procurada por pessoas que buscam a proteção de encantados e que acreditam no seu poder para desmanchar feitiços e curar diversas enfermedades ${ }^{1 "}$. As aproximações entre Bioética e Religiões Afro-ameríndias se dá em meio às leituras sobre Bioética de intervenção e de situações persistentes em Bioética e saúde pública, Traçaremos um plano entre Bioética e epistemologia. Para tanto, analisaremos o modo particular e emblemático como a Bioética emergente dos países periféricos se desenvolveu, assumindo bases epistemológicas próprias. A Bioética pensada a partir do Sul assume uma postura de crítica combativa ao naturalismo epistêmico que adota o modelo principialista $^{2}$ e universalista hegemónico imposto a partir do Norte, aproximando suas construções de um conjunto de concepções epistêmicas mais comprometidas com a realidade e com os problemas bioéticos que são próprios à realidade regional dos chamados países periféricos. Trata-se de um olhar que assume a prerrogativa epistêmica da observação da realidade concreta - e não mais de princípios supostamente universais - na compreensão e a enfrentamentos dos conflitos bioéticos persistentes e emergentes. Dessa forma, podemos conceber a bioética enquanto prática social, onde "requer abordagens pluralistas e transdisciplinares a partir de visões complexas da totalidade concreta que nos cerca e na qual vivemos." ${ }^{3}$ Sendo assim, o estudo sobre o Tambor de Cura em seu caráter ontológico e epistemológico representa mais uma vez a superação do racismo epistêmico ${ }^{4}$, e aponta garantir e ampliar o acesso à saúde da população negra, em particular as populações quilombolas e comunidades de terreiros, respeitando os saberes que estão presentes nesses grupos. E é sobre os saberes tradicionais da população negra que o Tambor de Cura, além de uma atividade religiosa, se apresenta sobre o olhar das epistemologias do Sul, enquanto uma práxis epistemológica, aquilo que está entre dois planos; entre a prática e a teoria. ${ }^{5}$

AGRADECIMENTOS: Os agredecimentos que seguem este trabalho são para o Programa de Pós-Graduação em Bioética onde estou fazendo o meu Doutorado, em especial ao Prof. Dr. Wanderson Flor, este meu orientador, e ao Prof. Dr.Volnei Garrafa, coordenador do PPGB e que muito tem contruido com a mina vida academica. Agradeço também ao Programa de Pós Gradução em Metafísca, programa onde fiz o meu mestrado e em especial ao Prof. Dr. Gabriele Corneli. E agradeço Também a Cappes que tem financiado esta pesquisa.

\section{REFERÊNCIAS}

[1] FERREIRA, E. M. Pajelança. São Luís: Estação Produções, 2003.

[2] GARRAFA, Volnei. Apresentando a Bioética. Universitas Face, Brasília, v. 2, n.2 - v. 3, n. 1. 2005.

[3] Volnei. Da bioética de princípios a uma bioética interventiva. Revista de Bioética Vol. 13, $\mathrm{n}^{\mathrm{o}}$ 1. 2005.

[4] CARNEIRO, Aparecida Sueli. A Construção do Outro como Não-Ser como fundamento do Ser. 2005. 339 fls. Tese (Doutorado em Educação) - Faculdade de Educação, Universidade de São Paulo, São Paulo, 2005.

[5] SÁNCHEZ VÁSQUEZ, Adolfo. Filosofia e circunstâncias. Tradutor: Luiz Guerra.Rio de Janeiro: Civilização Brasileira, 2002. 